\title{
The Ni(II) Complex of 2-Hydroxy-Pyridine- $N$-Oxide 2-Isothionate: Synthesis, Characterization, Biological Studies, and X-ray Crystal Structures using (1) Cu Ka Data and (2) Synchrotron Data
}

\author{
Mohamed A. Makhyoun ${ }^{a}$, Rex A. Palmer ${ }^{*}$, Amina A.Soayed ${ }^{a}$, Heba M. Refaat ${ }^{\mathrm{a}}$, Dina E. Basher ${ }^{* a}$, James \\ Raftery ${ }^{c}$, Carina M.C. Lobley ${ }^{\mathrm{d}}$, Anna J. Warren ${ }^{\mathrm{d}}$, Thomas Sorensen ${ }^{\mathrm{d}}$ and Mark Ladd ${ }^{\mathrm{e}}$
}

aDepartment of Chemistry, Alexandria University, Alexandria, Egypt

${ }^{b}$ Department of Crystallography, Birkbeck College, London, UK

'School of Chemistry, University of Manchester, Manchester, UK

${ }^{\mathrm{d} D i a m o n d}$ Light Source Ltd, Diamond House, Harwell Science and Innovation Campus, Didcot Oxfordshire, OX11

$0 \mathrm{DE}$

${ }^{e}$ Faculty of Health and Medical Sciences, University of Surrey, Guildford, UK

${ }^{*}$ Corresponding author: (1) Rex A. Palmer, Department of Crystallography, Biochemical Sciences, Birkbeck College, Malet Street, London WC1E7HX, UK, E-mail: rex.palmer@btinternet.com

(2) Dina E. Basher, Department of Chemistry, Faculty of Science, Alexandria University, Alexandria, P.O.Box 426- Ibrahimia, Alexandria 21321, Egypt, Fax: +203 3911 794, E-mail: dina_emam87@yahoo.com

Citation: Mohamed A. Makhyoun, Rex A. Palmer, Amina A.Soayed, Heba M. Refaat, Dina E. Basher, et al. (2014) The Ni(II) Complex of 2-Hydroxy-Pyridine-N-Oxide 2-Isothionate: Synthesis, Characterization, Biological Studies, and X-ray Crystal Structures using (1) Cu Ka Data and (2) Synchrotron Data. J Mater Sci Nanotechnol 2(1): 101. doi: 10.15744/2348-9812.1.301

Received Date: January 16, 2014 Accepted Date: March 6, 2014 Published Date: March 10, 2014

\begin{abstract}
$\mathrm{C}_{12} \mathrm{H}_{20} \mathrm{~N}_{6} \mathrm{NiO}_{6} \mathrm{~S}_{2}$ or $\left.\mathrm{NiL}_{2}(\mathrm{SCN})_{2}\right]\left(\mathrm{NH}_{4}\right)_{2} \cdot 2 \mathrm{H}_{2} \mathrm{O}$, where $\mathrm{L}$ is 2 -hydroxy-pyridine- $\mathrm{N}$-oxide, has been prepared and characterized using elemental analyses, IR, UV and visible spectrometry, magnetic moment measurements, thermal analyses and single crystal X-ray analyis. The results indicate that the complex reacts as a bidentate ligand and is bound to the metal ion via the two oxygen atoms of the ligand (HL). The activation energies, $\Delta E^{*}$, entropies $\Delta S^{*}$, enthalpies $\Delta H^{*}$ and order of reactions have been derived from differential thermogravimetric (DTA) curves. Based on inhibition zone diameter measurements, the complex exhibited significant antibacterial activity against both Staphylococcus aureus and Escherichia coli. It also exhibited significant antifungal activity against Candida albicans, but no activity was found against Aspergillus flavus. The crystal structure of the $\mathrm{Ni}(\mathrm{II})$ complex $\left[\mathrm{C}_{12} \mathrm{H}_{20} \mathrm{~N}_{6} \mathrm{Ni} \mathrm{O}_{6} \mathrm{~S}_{2}\right], \mathrm{Mr}=467.17$, was determined from $\mathrm{Cu} \mathrm{Ka} \mathrm{X-ray} \mathrm{diffraction} \mathrm{data,} \lambda=1.54178 \AA$, at $100 \mathrm{~K}$ using direct methods. The crystals are monoclinic, space group $\mathrm{P} 2{ }_{1} / \mathrm{n}$ with $\mathrm{Z}=4$ and $\mathrm{a}=8.9893(2) \AA ⿻$, $\mathrm{b}=17.6680(5) \AA, \mathrm{c}=12.5665(3) \AA, \beta=108.609(1)^{\circ}$. In parallel with this study corresponding results were derived for the crystal structure determined independently from synchrotron X-ray diffraction data, $\lambda=0.61990 \AA$, at $100 \mathrm{~K}$. The unit cell parameters derived in this experiment are $\mathrm{a}=9.000(2) \AA, \mathrm{b}=17.700(4) \AA, \mathrm{c}=12.590(3) \AA, \beta=108.61(3)^{\circ}$. Both studies show $4 \mathrm{O}$ and $2 \mathrm{~N}$ atoms coordinating $\mathrm{Ni}$ in a distorted octahedral arrangement. Each of the Ni 2-hydroxy-pyridinium- $N$-oxide moieties is highly planar and the $\mathrm{S}=\mathrm{C}=\mathrm{N}-\mathrm{Ni}$ ligands are approximately linear. The crystal structure is characterised by a number of strong hydrogen bonds.
\end{abstract}

Keywords: 2-Hydroxy-pyridine- $N$-oxide derivatives; Infrared; Ultraviolet; DTG (Differential thermo-gravimetric); TGA (Thermogravimetric ); DTA (Differential thermal analysis ); X-ray crystal structure: $\mathrm{Cu} \mathrm{Ka}$ and synchrotron data; Biological properties

\section{Introduction}

Compounds containing $N$-oxides and sulphur possess important biological activity [1,2]. Compounds containing sulphur, as well as their metal complexes exhibit numerous biochemical applications [3-5]. 2-Hydroxy-pyridine- $\mathrm{N}$-oxide (HOPNO) [6] and 2-mercaptopyridine- $N$-oxide (HSPNO) $[7,8]$ have been described as new and efficient transition-state analog (TS-analog) inhibitors for the mushroom tyrosinase enzyme. 2-Hydroxy-pyridine- $N$-oxide derivatives have been shown to remove iron from human transferrin and horse spleen ferritin at $\mathrm{pH} 7.4$ at levels higher than those caused by desferrioxamine [8]. The intraperitoneal and intragastric administration of 2,4-dihydroxypyridine- $N$-oxide to iron-loaded ${ }^{59} \mathrm{Fe}$-labelled mice caused an increase in ${ }^{59} \mathrm{Fe}$ excretion comparable to that caused by intraperitoneal desferrioxamine. These results increase the prospects for the use of these chelators as probes for studying iron metabolism and in the treatment of iron overload and other diseases of iron imbalance [8]. 2-Hydroxy- $N$-oxide is also now used as a wood preservative to prevent fungal decay and insect attack [9]. Moreover, pyridine $\mathrm{N}$-oxide derivatives are also employed in the oxidation of alkyl halides to aldehydes, due to the relative ease of deoxygenation 
compared to deoxygenation of tertiary amine oxides [10].

\section{Experimental}

\section{Materials}

The organic ligand 2-hydroxy-pyridine- $N$-oxide (HOPO) was purchased from Aldrich and used without further purification. Analytical grade nickel chloride, absolute ethanol, distilled water, dimethyl formamide (DMF) and dimethyl sulfoxide (DMSO) were purchased from the El-Gomhoria Company, Alexandria and used without further purification.

\section{Synthesis of the $\mathrm{Ni}(\mathrm{II})$ complex- $\left[\mathrm{NiL}_{2}(\mathrm{SCN})_{2}\right] \cdot 2 \mathrm{NH}_{4} \cdot 2 \mathrm{H}_{2} \mathrm{O}$ :}

To a solution of 2-hydroxy-pyridine- $\mathrm{N}$-oxide (I) (HL) (0.11 gm i.e. $1 \mathrm{mmol}$ in $10 \mathrm{~mL}$ hot ethanol), a solution of $\mathrm{NiCl}_{2} \cdot 6 \mathrm{H}_{2} \mathrm{O}$ (0.24g i.e. $1 \mathrm{mmol}$ in $10 \mathrm{~mL}$ ethanol) was added with constant stirring.

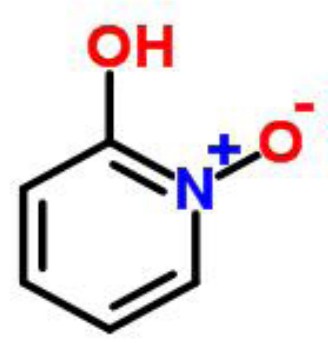

(I) 2-Hydroxy-pyridine- $\mathrm{N}$-oxide (HL) also known as 2-pyridinol- $\mathrm{N}$-oxide

Solid $\mathrm{NH}_{4} \mathrm{SCN}(0.5 \mathrm{gm})$ was added and the reaction mixture was refluxed on a water bath for $2 \mathrm{~h}$, cooled and left at room temperature for $48 \mathrm{~h}$. The isolated crystals were then filtered off, washed several times with EtOH followed by Et ${ }_{2} \mathrm{O}$ and recrystallized from $\mathrm{H}_{2} \mathrm{O}$. The lustrous green crystals were filtered off, washed several times with $\mathrm{Et}_{2} \mathrm{O}$, dried under vacuum and kept over $\mathrm{P}_{4} \mathrm{O}_{10}$. This procedure did, however, unexpectedly leave the hydrated water intact, an effect reported previously, for example by Agarwal and Rastogi [11]. The reaction scheme is shown in Figure 1.

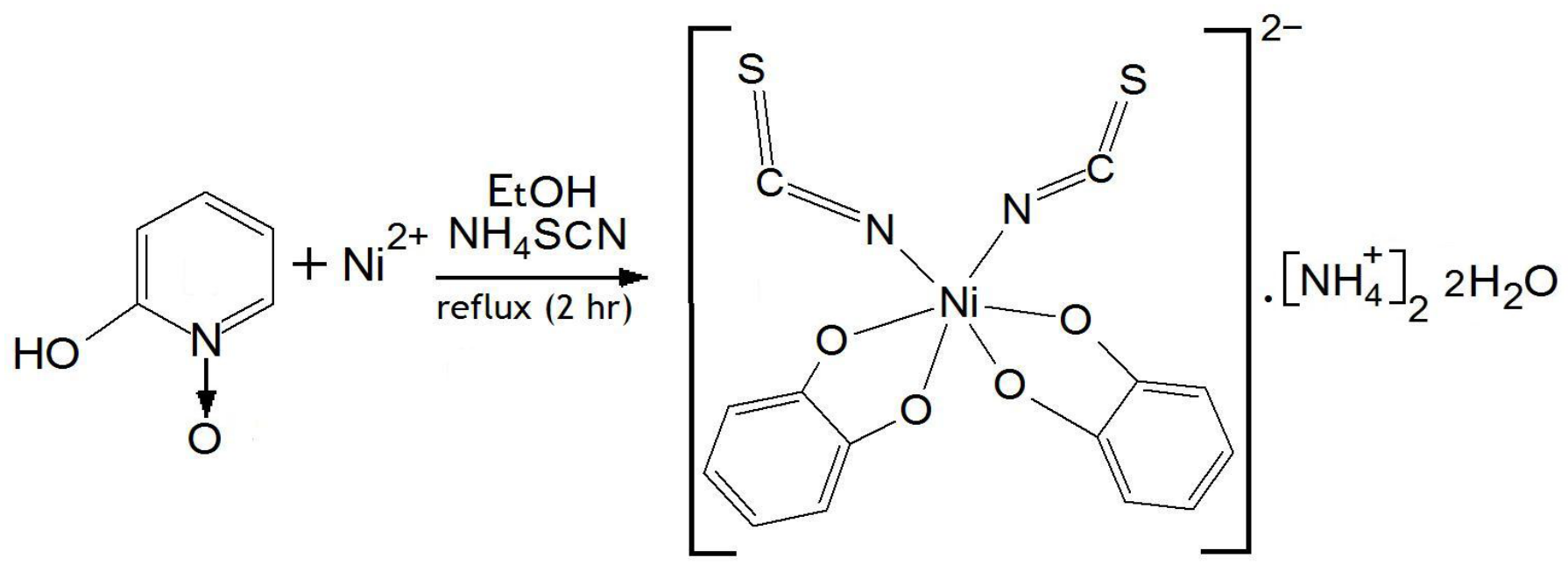

Figure1: Scheme for the synthesis of the $\mathrm{Ni}(\mathrm{II})$ complex: $\left[\mathrm{NiL}_{2}(\mathrm{SCN})_{2}\right] .\left(\mathrm{NH}_{4}\right)_{2} 2 \mathrm{H}_{2} \mathrm{O}$.

\section{Physicochemical studies}

The Fourier transform infrared (FT-IR) spectra of the ligand and solid nickel(II) complex were recorded on a Perkin Elmer 2000 FT-IR spectrometer. Data were collected at a resolution of $4 \mathrm{~cm}^{-1}$. The solid sample was measured as a KBr pellet in the 4000-370 $\mathrm{cm}^{-1}$ spectral range. Nujol mull electronic UV-Vis spectra were recorded in the $190-900 \mathrm{~nm}$ range. The spectrophotometer measurements in the visible and ultraviolet regions were made with a Thermo scientific Evolution 300 UV-visible spectrophotometer. Absorbance was calibrated using a standard solution of $\mathrm{CoCl}_{2}$ or $\mathrm{K}_{2} \mathrm{CrO}_{4}$. The absorption spectra of the solutions were measured using $1.0 \mathrm{~cm}$ silica cells. Molar magnetic susceptibilities, were determined with a JEOL (JES-FE2XG) ESR spectrometer at room temperature $(298 \mathrm{~K})$ using Gouy's method, and corrected for diamagnetism using Pascal's constants, and $\mathrm{Hg}\left[\mathrm{Co}(\mathrm{SCN})_{4}\right]$ as a calibrant. The metal ion content was determined using a computer controlled 850-Fisher Jarrell ash atomic absorption spectrophotometer. The analyses of C, H, and $\mathrm{N}$ were performed using an Elementar Vario El (III) elemental analyser. Thermal analyses (TG, 
DTG and DTA) were carried out in an $\mathrm{N}_{2}$ atmosphere with a heating rate $10{ }^{\circ} \mathrm{C} \mathrm{min}^{-1}$ using a Shimadzu TGA $50 \mathrm{H}$ and a DTA 50 thermal analyzer. The Shimadzu instrument which uses a single light source and one optical system does not require calibration.

\section{Antimicrobial studies}

Antimicrobial screening tests were conducted at the Microanalytical Centre, Faculty of Science, Cairo University. The antimicrobial activity of the test samples was determined using a modified Kirby-Bauer disc diffusion method [12]. The synthesized compound was dissolved to prepare a stock solution of $1 \mathrm{mg} / \mathrm{mL}$ using DMSO. Stock solution was aseptically transferred and two-fold diluted to provide solutions of different concentrations. The antibacterial and antifungal activities were determined by measuring the diameters of the inhibition zone $(\mathrm{mm})$ with DMSO as a control. The cultures were routinely maintained on nutrient agar (NA) and incubated at $37^{\circ} \mathrm{C}$. Bacterial or fungal inoculates were obtained by diluting stock bacterial or fungal culture suspensions (100 $\mathrm{mL}$ volumes of growing cultures in NA broth at $37^{\circ} \mathrm{C}$ overnight) and were spread uniformly onto NA plates. Solutions of the tested compound and reference drugs were prepared by dissolving $10 \mathrm{mg}$ of the compound in $10 \mathrm{~mL}$ of DMSO. Approximately, $0.1 \mathrm{~mL}$ of each sample was pipetted into a well (depth $3 \mathrm{~mm}$ ) made in the centre of the agar. Sterile $8 \mathrm{~mm}$ discs were impregnated with test compound. The disc was placed onto the plate. Each plate had one control disc impregnated with solvent. The plates were incubated at $37^{\circ} \mathrm{C}$ for $18-48 \mathrm{~h}$. Standard discs of tetracycline (antibacterial agent; $10 \mu \mathrm{g} / \mathrm{disc}$ ) and amphotericin B (antifungal agent; $10 \mathrm{mg} /$ disc) served as positive controls for antimicrobial activity while filter discs impregnated with $10 \mu \mathrm{l}$ of solvent DMSO were used as a negative control.

\section{$\mathrm{X}$-ray analysis}

Crystals formed when the refluxed reaction mixture was cooled and left at room temperature for 48 h. They were filtered off, washed several times with EtOH followed by $\mathrm{Et}_{2} \mathrm{O}$ and then recrystallized from $\mathrm{H}_{2} \mathrm{O}$. The lustrous green crystals were filtered off, washed several times with $\mathrm{Et}_{2} \mathrm{O}$, dried under vacuum and kept over $\mathrm{P}_{4} \mathrm{O}_{10}$. Crystal sizes varied from $(0.18-0.50) \mathrm{x}(0.15-0.50) \mathrm{x}$ $(0.14-0.30) \mathrm{mm}^{3}$.

$\mathrm{Cu}$ Ka Structure: A crystal with dimensions $0.18 \times 0.15 \times 0.14 \mathrm{~mm}^{3}$ was used for data collection. Intensity data were collected using monochromated $\mathrm{Cu}$ Ka radiation, $\lambda=1.54178 \AA$, on a Bruker Prospector diffractometer, and processed with the SAINT data processing program $[13,14]$. The diffractometer was equipped with an Oxford Cryosystems Cryostream Controller 700 [15], enabling the data to be collected at $100 \mathrm{~K}$. The crystal showed no significant variation in intensity during the course of data collection. A total of 11142 reflections was collected which reduced to 3448 independent reflections $(\mathrm{R}(\mathrm{int})=0.0455)$. The structure was solved using SHELX-86 [16] and refined using SHELX-97 [17] implemented on the WinGX [18] system of programs. Hydrogen atoms were refined in riding mode with tied isotropic temperature factors. The chemical formula and atom numbering are shown in Figure 2. Figure 3(a) is an Ortep [19] plot rendered by RASTER 3D [20] excluding the $\mathrm{NH}_{4}^{+}$and $\mathrm{H}_{2} \mathrm{O}$ solvates. Figure 3b shows the distorted octahedral coordination of the $\mathrm{Ni}$ atom by $2 \mathrm{~N}$ atoms and $4 \mathrm{O}$ atoms drawn with MERCURY [39]. Table 1a summarizes the essential crystal and X-ray analysis refinement data.

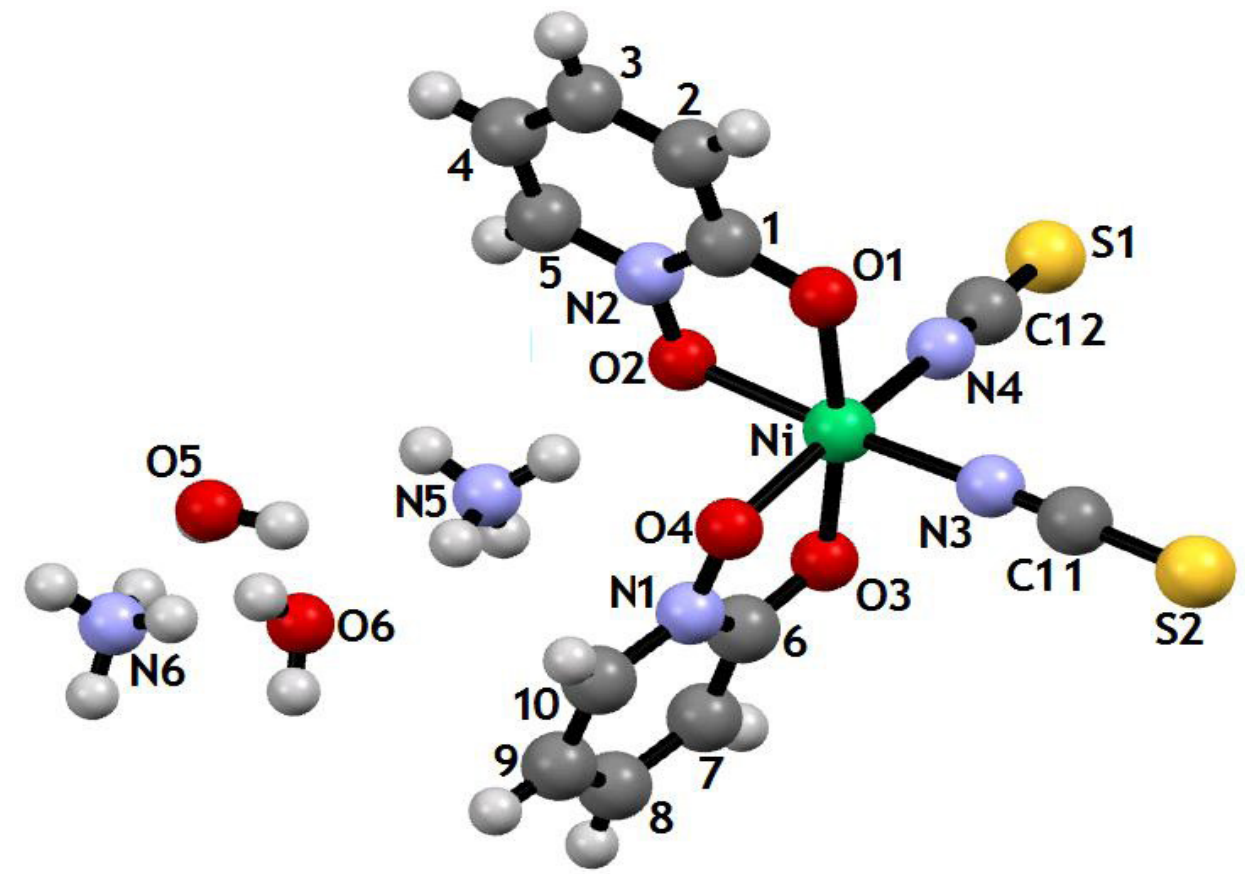

Figure 2: MERCURY [39] plot derived from the X-ray structure of the $\mathrm{Ni}(\mathrm{II})$ complex: $\left[\mathrm{NiL}_{2}(\mathrm{SCN})_{2}\right] .\left(\mathrm{NH}_{4}\right)_{2} 2 \mathrm{H}_{2} \mathrm{O}$. The atom numbering used in the two X-ray structure analyses is shown. 


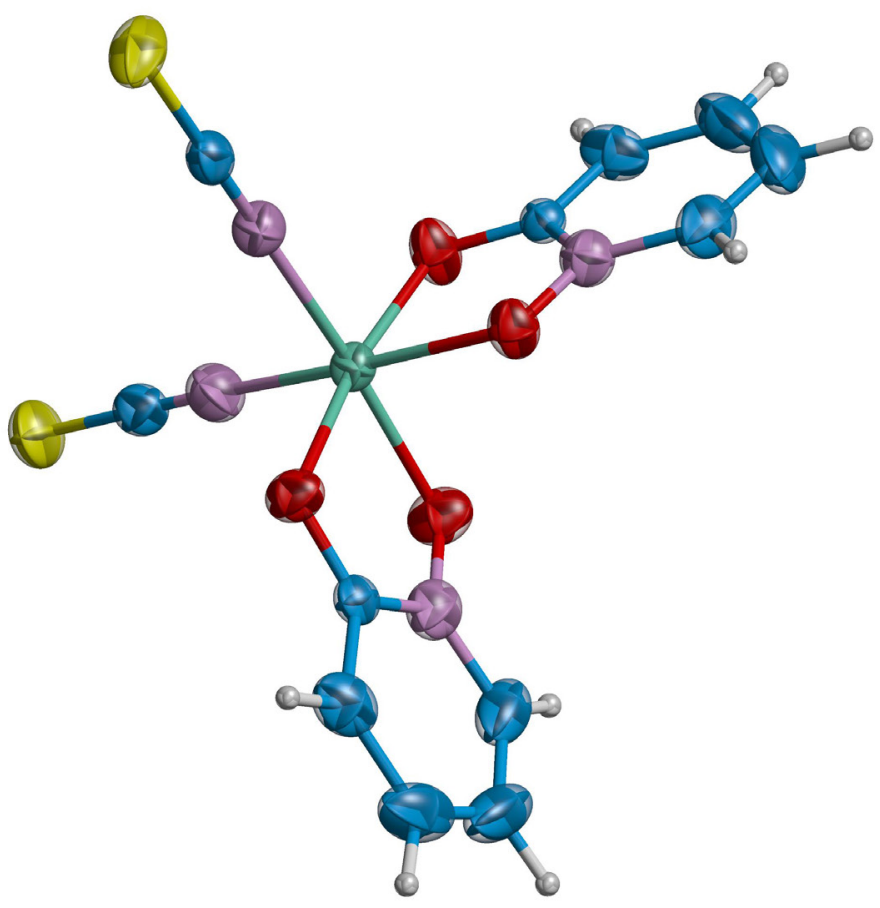

Figure 3a: Ortep [19] plot rendered by RASTER 3D [20] excluding the $\mathrm{NH}_{4}{ }^{+}$and $\mathrm{H}_{2} \mathrm{O}$ solvates. Thermal ellipsoids are drawn at $95 \%$ probability.

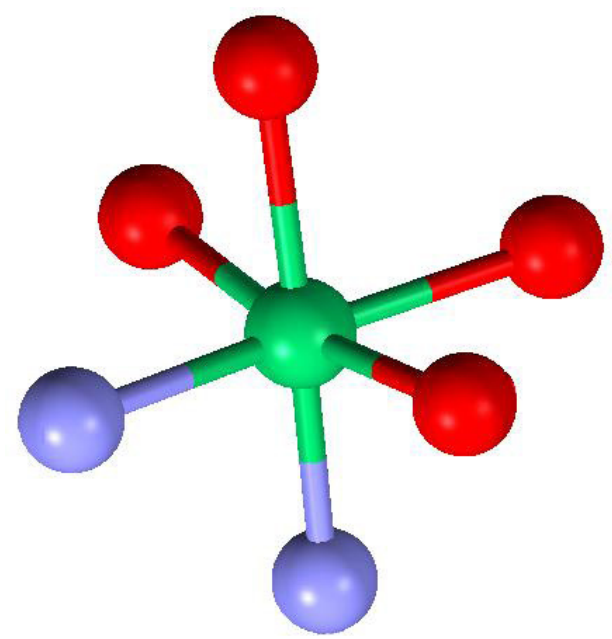

Figure 3b: Distorted octahedral coordination of the $\mathrm{Ni}$ atom (green) by $2 \mathrm{~N}$ atoms (blue) and $4 \mathrm{O}$ atoms (red) drawn with MERCURY [39]. 


\begin{tabular}{|c|c|c|}
\hline Identification code & Ni Complex 13 & \\
\hline Empirical formula & $\mathrm{C}_{12} \mathrm{H}_{20} \mathrm{~N}_{6} \mathrm{NiO}_{6} \mathrm{~S}_{2}$ & \\
\hline Formula weight & 467.17 & \\
\hline Temperature & $100(2) \mathrm{K}$ & \\
\hline Wavelength & $1.54178 \AA$ & \\
\hline Crystal system & Monoclinic & \\
\hline Space group & $\mathrm{P} 2_{1} / \mathrm{n}$ & \\
\hline \multirow[t]{3}{*}{ Unit cell dimensions } & $\mathrm{a}=8.9893(2) \AA$ & $\alpha=90^{\circ}$. \\
\hline & $\mathrm{b}=17.6680(5) \AA$ & $\beta=108.609(1)^{\circ}$. \\
\hline & $c=12.5665(3) \AA$ & $\gamma=90^{\circ}$. \\
\hline Volume & 1891.50(8) ^̊3 & \\
\hline $\mathrm{Z}$ & 4 & \\
\hline Density (calculated) & $1.641 \mathrm{Mg} / \mathrm{m}^{3}$ & \\
\hline Absorption coefficient & $3.945 \mathrm{~mm}^{-1}$ & \\
\hline $\mathrm{F}(000)$ & 968 & \\
\hline Crystal size & $0.18 \times 0.15 \times 0.14 \mathrm{~mm}^{3}$ & \\
\hline Theta range for data collection & 4.48 to $68.24^{\circ}$. & \\
\hline Index ranges & $-10<=\mathrm{h}<=10,-20<=\mathrm{k}<=21,-15<=\mathrm{l}<=15$ & \\
\hline Reflections collected & 11142 & \\
\hline Independent reflections & $3448[\mathrm{R}(\mathrm{int})=0.0455]$ & \\
\hline Completeness to theta $=66.60^{\circ}$ & $99.8 \%$ & \\
\hline Absorption correction & Semi-empirical from equivalents & \\
\hline Max. and min. transmission & 0.6081 and 0.39725 & \\
\hline Refinement method & Full-matrix least-squares on $\mathrm{F}^{2}$ & \\
\hline Data / restraints / parameters & 3448 / 2 / 292 & \\
\hline Goodness-of-fit on $\mathrm{F}^{2}$ & 1.011 & \\
\hline Final $R$ indices $[\mathrm{I}>2 \operatorname{sigma}(\mathrm{I})]$ & $\mathrm{R} 1=0.0330, \mathrm{wR} 2=0.0823$ & \\
\hline $\mathrm{R}$ indices (all data) & $\mathrm{R} 1=0.0412, \mathrm{wR} 2=0.0867$ & \\
\hline Largest diff. peak and hole & 0.573 and -0.358 e..$\AA^{-3}$ & \\
\hline
\end{tabular}

Table 1a: Crystal and structure refinement data using conventional $\mathrm{Cu} \mathrm{X}$-ray source

Synchrotron Structure: The crystal used for data collection was $0.30 \times 0.50 \times 0.50 \mathrm{~mm}^{3}$ and was mounted on a SPINE standard pin in $30 \%$ glycerol. Intensity data were collected on the macromolecular crystallography (MX) beamline I02 at Diamond Light Source. In order to optimize data collection, the beamline was operated at $20 \mathrm{keV}$ giving $\lambda=0.61990 \AA$. Intensity data were measured using a Pilatus $6 \mathrm{M}$ detector at a distance of $179.5 \mathrm{~mm}$ and processed with the Xia2 with the 3dii option [21-28] and scaled using the XPREP software from Bruker (www.bruker.com). As an MX beamline, I02 is equipped with an Oxford Instruments cryojetXL cryostream. Data were collected at $100 \mathrm{~K}$. A total of 29239 reflections were collected which reduced to 5011 independent reflections $(\mathrm{R}(\mathrm{int})=0.0205)$. The structure was solved and refined as described above for the $\mathrm{Cu}$ Ka data. Table $1 \mathrm{~b}$ summarizes the essential crystal and X-ray analysis refinement data.

\section{Results and Discussion}

The chelating properties of 2-hydroxy-pyridine $N$-oxide (HL) (I), behaving as a heterocyclic analog of hydroxamic acids, have been reported previously by potentiometric and spectrophotometric methods for several divalent and trivalent metals. Divalent metal ions such as magnesium (II), calcium (II), cobalt (II), nickel (II), copper (II), and zinc (II)] have also been used in chelation studies, the nickel (II) ion being chosen for the present study.

The $\mathrm{NiL}_{2}(\mathrm{SCN})_{2} \cdot\left(\mathrm{NH}_{4}\right)_{2} \cdot 2 \mathrm{H}_{2} \mathrm{O}$ complex was formed as result of the reaction between 2-pyridinol- $\mathrm{N}$-oxide and $\mathrm{NiCl} \mathrm{Cl}_{2}$ salt in the presence of $\mathrm{NH}_{4} \mathrm{SCN}$. Analytical data for the organic compound and the complex are presented in Table 2 . Figure 2 shows the chemical scheme derived from the X-ray analysis.

\section{Infrared spectroscopy}

The FTIR absorption bands of the Ni(II) complex have been compared with those of the free ligand (Table 3) in order to determine the bonding sites in the complex. The ligand exhibits an absorption band at $3331 \mathrm{~cm}^{-1}$ due to the presence of an $\mathrm{OH}$ group. The 
nitroso group is located at $1446 \mathrm{~cm}^{-1}$ [29]. The $\mathrm{N}-\mathrm{O}$ bending frequency of the aromatic nitroso group is assigned to the band at 842 $\mathrm{cm}^{-1}[30,31]$. The $\delta \mathrm{O}---\mathrm{H}-\mathrm{O}$ mode of vibration is identified as the band at $1548 \mathrm{~cm}^{-1}$ for nitroso and $\mathrm{OH}$ groups. In the Ni(II) complex, a band at $3467 \mathrm{~cm}^{-1}$ was attributed to $v \mathrm{H}_{2} \mathrm{O}$; the $\mathrm{OH}$ groups were eliminated during this process as revealed by IR (this corresponds to these groups coordinating with the $\mathrm{Ni}$ (II) ion). Strong bands at 2082 and 2148 (Table 3) were assigned to the $v(\mathrm{SCN}$ ) group [32]. The $\mathrm{NH}_{4}^{+}$ion shows a band at $3214 \mathrm{~cm}^{-1}$ resulting from a $\mathrm{NH}_{4}^{+}$anti-symmetric stretching vibration and another strong absorption band at $1394 \mathrm{~cm}^{-1}$ resulting from an $\mathrm{NH}_{4}^{+}$bending vibration. The other bands in the region between 1450 and $1600 \mathrm{~cm}^{-1}$ arise mainly from pyridine ring vibrations.

\begin{tabular}{|c|c|c|}
\hline Identification code & Ni Complex 13 & \\
\hline Empirical formula & $\mathrm{C}_{12} \mathrm{H}_{20} \mathrm{~N}_{6} \mathrm{Ni} \mathrm{O}_{6} \mathrm{~S} 2 \mathrm{a}$ & \\
\hline Formula weight & 467.16 & \\
\hline Temperature & $100(2) \mathrm{K}$ & \\
\hline Wavelength & $0.61990 \AA$ & \\
\hline Crystal system & Monoclinic & \\
\hline Space group & $\mathrm{P} 2 / \mathrm{n}$ & \\
\hline \multirow[t]{3}{*}{ Unit cell dimensions } & $\mathrm{a}=9.0000(18) \AA$ & $\alpha=90^{\circ}$. \\
\hline & $\mathrm{b}=17.700(4) \AA$ & $\beta=108.61(3)^{\circ}$. \\
\hline & $\mathrm{c}=12.590(3) \AA$ & $\gamma=90^{\circ}$. \\
\hline Volume & $1900.7(7) \AA^{3}$ & \\
\hline $\mathrm{Z}$ & 4 & \\
\hline Density (calculated) & $1.632 \mathrm{Mg} / \mathrm{m}^{3}$ & \\
\hline Absorption coefficient & $0.821 \mathrm{~mm}^{-1}$ & \\
\hline $\mathrm{F}(000)$ & 968 & \\
\hline Crystal size & $0.30 \times 0.50 \times 0.50 \mathrm{~mm}^{3}$ & \\
\hline Theta range for data collection & 1.80 to $25.12^{\circ}$. & \\
\hline Index ranges & $-12<=\mathrm{h}<=12,-23<=\mathrm{k}<=23,-17<=\mathrm{l}<=17$ & \\
\hline Reflections collected & 28469 & \\
\hline Independent reflections & $5011[\mathrm{R}(\mathrm{int})=0.0205]$ & \\
\hline Completeness to theta $=25.12^{\circ}$ & $98.0 \%$ & \\
\hline Max. and min. transmission & 0.7908 and 0.6844 & \\
\hline Refinement method & Full-matrix least-squares on $\mathrm{F}^{2}$ & \\
\hline Data / restraints / parameters & $5011 / 0 / 325$ & \\
\hline Goodness-of-fit on $\mathrm{F}^{2}$ & 1.118 & \\
\hline Final $\mathrm{R}$ indices $[\mathrm{I}>2 \operatorname{sigma}(\mathrm{I})]$ & $\mathrm{R} 1=0.0220, \mathrm{wR} 2=0.0587$ & \\
\hline $\mathrm{R}$ indices (all data) & $\mathrm{R} 1=0.0220, \mathrm{wR} 2=0.0587$ & \\
\hline Extinction coefficient & $0.0342(12)$ & \\
\hline Largest diff. peak and hole & 0.467 and -0.490 e. $\AA \AA-3$ & \\
\hline
\end{tabular}

Table 1b: Crystal and structure refinement data using Synchrotron X-ray source

\begin{tabular}{|c|c|c|c|c|c|}
\hline Compound & $\begin{array}{c}\% \mathrm{C} \\
\text { Found (calculated) }\end{array}$ & $\begin{array}{c}\% \mathrm{H} \\
\text { Found (calculated) }\end{array}$ & $\begin{array}{c}\% \mathrm{~N} \\
\text { Found (calculated) }\end{array}$ & $\begin{array}{c}\% S \\
\text { Found (calculated) }\end{array}$ & $\begin{array}{c}\% \mathrm{Ni} \\
\text { Found (calculated) }\end{array}$ \\
\hline $\begin{array}{c}\text { 2-hydroxy-pyridine- } N \text { - oxide } \\
\text { (HL) }\end{array}$ & $\begin{array}{c}54.437 \\
(54.054)\end{array}$ & $\begin{array}{c}4.189 \\
(4.504)\end{array}$ & $\begin{array}{c}11.989 \\
(12.612)\end{array}$ & -- & -- \\
\hline$\left[\mathrm{NiL}_{2}(\mathrm{SCN})_{2}\right] \cdot\left(\mathrm{NH}_{4}\right)_{2} 2 \mathrm{H}_{2} \mathrm{O}$ & $\begin{array}{c}29.05 \\
(30.855)\end{array}$ & $\begin{array}{c}5.14 \\
(4.315)\end{array}$ & $\begin{array}{c}17.28 \\
(17.99)\end{array}$ & $\begin{array}{l}13.800 \\
(13.73)\end{array}$ & $\begin{array}{c}13.73 \\
(12.524)\end{array}$ \\
\hline
\end{tabular}

Table 2: Analytical data for the ligand and $\left[\mathrm{NiL}_{2}(\mathrm{SCN})_{2}\right] \cdot\left(\mathrm{NH}_{4}\right)_{2} 2 \mathrm{H}_{2} \mathrm{O}$ complex.

\begin{tabular}{|l|l|l|l|l|l|l|l|l|l|l|}
\hline Compound & $v \mathrm{H}_{2} \mathrm{O}$ & $v \mathrm{OH}$ & $v \mathrm{CH}$ & $\delta \mathrm{O} \ldots \mathrm{HO}$ & $v \mathrm{~N}-\mathrm{O}$ & $v \mathrm{SCN}$ & $v \mathrm{NH}_{4}^{+}$ & $\delta$ NO bending & $v \mathrm{NH}_{4}^{+}$bending & $\begin{array}{l}v \mathrm{M}-\mathrm{O} \\
v \mathrm{M}-\mathrm{N}\end{array}$ \\
\hline $\begin{array}{l}\text { 2-hydroxy-pyridinum- } \\
\mathrm{N} \text { - oxide (HL) }\end{array}$ & & 3331 & $\begin{array}{l}2973 \\
2900\end{array}$ & & 1446 & & & 880 & \\
\hline $\begin{array}{l}{\left[\mathrm{NiL}_{2}(\mathrm{SCN})_{2} \cdot\right] .} \\
2 \mathrm{NH}_{4} \cdot 2 \mathrm{H}_{2} \mathrm{O}\end{array}$ & 3467 & & 2987 & 1548 & 1568 & 2148 & 3214 & 883 & 1394 \\
\end{tabular}

Table 3: IR band assignments $\left(\mathrm{cm}^{-1}\right)$ for the ligand and $\mathrm{Ni}(\mathrm{II})$ complex. 
The electronic absorption spectrum (see Supplementary Information)

$\left[\mathrm{NiL}_{2}(\mathrm{SCN})_{2}\right] .\left(\mathrm{NH}_{4}\right)_{2} 2 \mathrm{H}_{2} \mathrm{O}$ possesses d-d transition bands at $400 \mathrm{~nm}$, a broad band centred at 690, 920 and $1110 \mathrm{~nm}$, respectively as a result of ${ }^{3} \mathrm{~A}_{2 \mathrm{~g}} \rightarrow{ }^{3} \mathrm{~T}_{1 \mathrm{~g}}(\mathrm{P}),{ }^{3} \mathrm{~A}_{2 \mathrm{~g}} \rightarrow{ }^{1} \mathrm{E}_{\mathrm{g}}+{ }^{3} \mathrm{~T}_{1 \mathrm{~g}}(\mathrm{~F}),{ }^{3} \mathrm{~A}_{2 \mathrm{~g}} \rightarrow{ }^{3} \mathrm{~T}_{2 \mathrm{~g}}$, transitions, respectively, in an octahedral structure [33]. This was confirmed by a magnetic moment value of 3.6 B.M.

\section{Thermal analyses}

The TGA thermal behaviour of $\left[\mathrm{NiL}_{2}(\mathrm{SCN})_{2}\right] .\left(\mathrm{NH}_{4}\right) 22 \mathrm{H}_{2} \mathrm{O}$ complex was studied (Figure 4) and revealed that the complex decomposed in three steps. The first between $52-287^{\circ} \mathrm{C}$ with DTG $=72.84{ }^{\circ} \mathrm{C}, 110.50{ }^{\circ} \mathrm{C}$ and $254.16{ }^{\circ} \mathrm{C}$ where $2 \mathrm{H}_{2} \mathrm{O}, 2 \mathrm{NH}_{4}^{+}, 2 \mathrm{SCN}$ and $2 \mathrm{CH}=\mathrm{NO}$ moieties were lost (found: $59.148 \%$; calc. $58.652 \%$ ). The second process occurred between $287-329^{\circ} \mathrm{C}$, with $\mathrm{DTG}=$ $307.12{ }^{\circ} \mathrm{C}$, is due to the loss of a CO (carbon monoxide) molecule, (found: $6.789 \%$; calc: $5.994 \%$ ). The third step starts at 329 and ends at $575{ }^{\circ} \mathrm{C}$ with DTG $=352.67$ and $524.41^{\circ} \mathrm{C}$ assigned to the decomposition of $\mathrm{CH}_{2}=\mathrm{CH}_{2}+\mathrm{CH}_{2}+\mathrm{CH} . \mathrm{CH}=\mathrm{CH}_{2}$ moieties and left with a residue of $\mathrm{NiO}$ (found $16.646 \%$; calc: $15.990 \%$ ). The DTA of this complex shows four endothermic peaks below $350{ }^{\circ} \mathrm{C}$ namely at $77.84,110.45,256.66$ and $309.96{ }^{\circ} \mathrm{C}$, attributed to the loss of $2 \mathrm{H}_{2} \mathrm{O}, 2 \mathrm{NH}_{4}^{+}, 2 \mathrm{SCN}, 2 \mathrm{CH}=\mathrm{NO}$ and $\mathrm{CO}$ moieties and an exothermic peak at $527.31^{\circ} \mathrm{C}$.

The thermodynamic parameters of the decomposition processes of $\left[\mathrm{NiL}_{2}(\mathrm{SCN})_{2}\right] .\left(\mathrm{NH}_{4}\right)_{2} 2 \mathrm{H}_{2} \mathrm{O}$ complex, namely, activation energy $\mathrm{E}_{\mathrm{a}}{ }^{\theta}$, enthalpy of reaction $\left(\Delta \mathrm{H}^{\theta}\right)$, entropy $\left(\Delta \mathrm{S}^{\theta}\right)$ were evaluated by employing the Horowitz-Metzger equation [34].

The order of chemical reactions (n) was calculated via the peak symmetry method, Kissinger [35]. The asymmetry of a peak or trough, As, was calculated as follows:

$$
\mathrm{A}_{\mathrm{s}}=0.63 \mathrm{n}^{2} \text { where } \mathrm{n}=1.26(\mathrm{a} / \mathrm{b})^{1 / 2}
$$

Where $\mathrm{a}$ and $\mathrm{b}$ are derived from the DTA curve as indicated in Figure 4.

The values of collision factor, $Z$, also known as the frequency factor [34] were hand calculated using the relation [36]:

$\mathrm{Z}=\left(\mathrm{E}_{\mathrm{a}}{ }^{\theta} / \mathrm{RT}_{\mathrm{m}}\right) \beta \exp \left(\mathrm{E}_{\mathrm{a}}{ }^{\theta} / \mathrm{RT}_{\mathrm{m}}\right)$

where $\mathrm{R}$ is the molar gas constant, $\beta$ is the heating rate $\left(\mathrm{kA}_{\mathrm{s}}^{-1}\right)$, Tm is the maximum temperature for an exothermic transition or the minimum temperature for an endothermic transition in the DTA outputs. See reference [34] equation $9^{1}$.

The entropies of activation $\Delta \mathrm{S}^{\theta}$ are calculated from:

$$
\mathrm{Z}=\left(\mathrm{kT} \mathrm{T}_{\mathrm{m}} / \mathrm{h}\right) \exp \Delta \mathrm{S}^{\theta} / \mathrm{R}
$$

Where $\mathrm{k}$ is the Boltzmann constant and $\mathrm{h}$ is Planck's constant.

The change in enthalpy $\left(\Delta \mathrm{H}^{\theta}\right)$, taking place at any peak temperature, $\mathrm{T}_{\mathrm{m}}$ is given by: $\left(\Delta \mathrm{S}^{\theta}\right)=\Delta \mathrm{H}^{\theta} / \mathrm{T}_{\mathrm{m}}$.

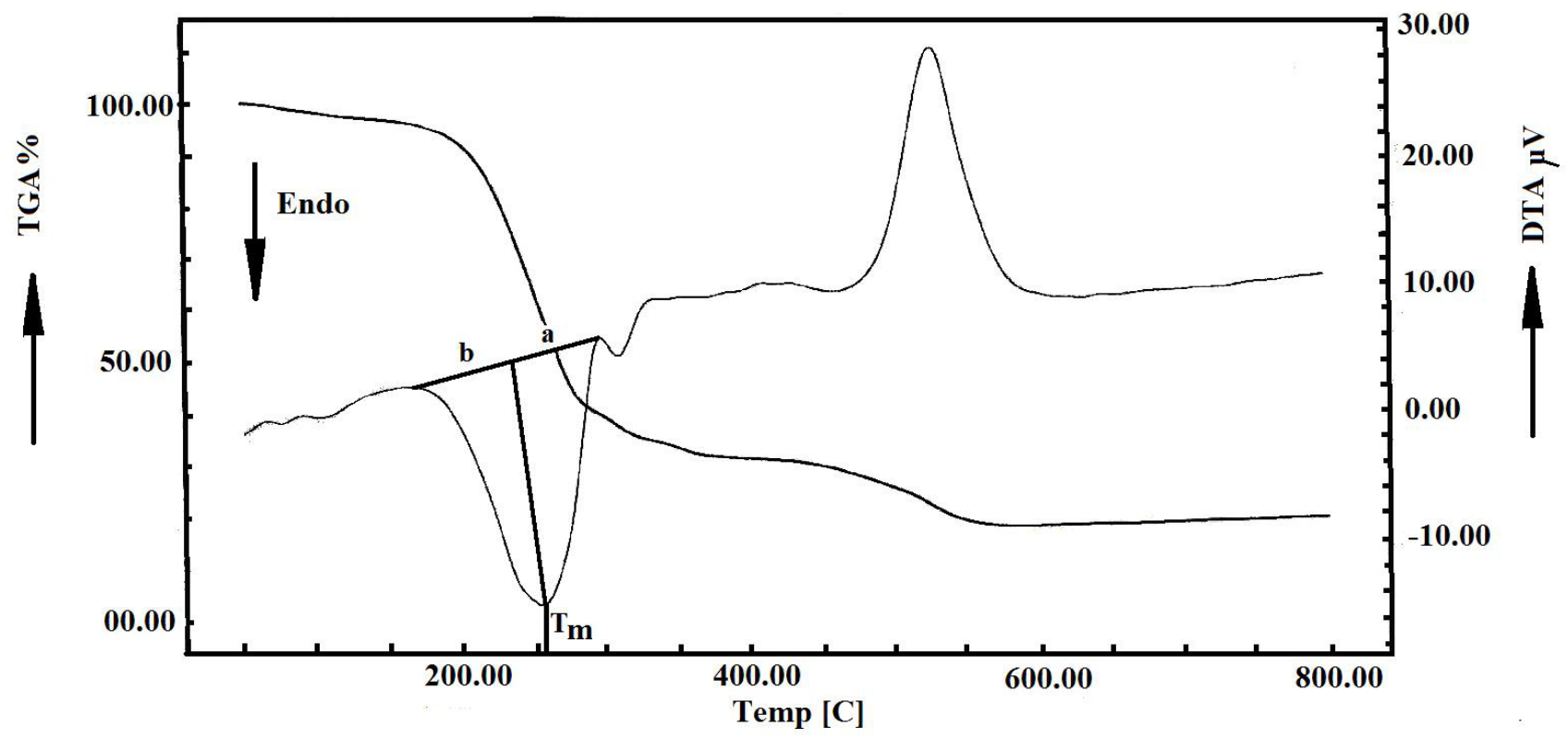

Figure 4: TGA and DTA curves of $\left[\mathrm{NiL}_{2}(\mathrm{SCN})_{2}\right] \cdot\left(\mathrm{NH}_{4}\right)_{2} 2 \mathrm{H}_{2} \mathrm{O}$. The a and b parameters used in the calculation of the asymmetry $\mathrm{A}$ s of an endotherm trough on the DTA curve are indicated. The asymmetry of an exotherm peak can be derived using a comparable method.

${ }^{1}$ Note reference [36] does not give the correct expression for $\mathrm{Z}$ 
Measurements of $\Delta \mathrm{t}$ were made on the curve (Figure 5) corresponding to different temperatures. Based on least squares calculations, the $\ln (\Delta \mathrm{t})$ v. 1000/T plots for the complex, gave straight lines from which the activation energies were calculated according to the method of Piloyan et al.[37]. The slope is of the Arrhenius type and equals $-\mathrm{E}_{\mathrm{a}}{ }^{\theta} / \mathrm{R}$.

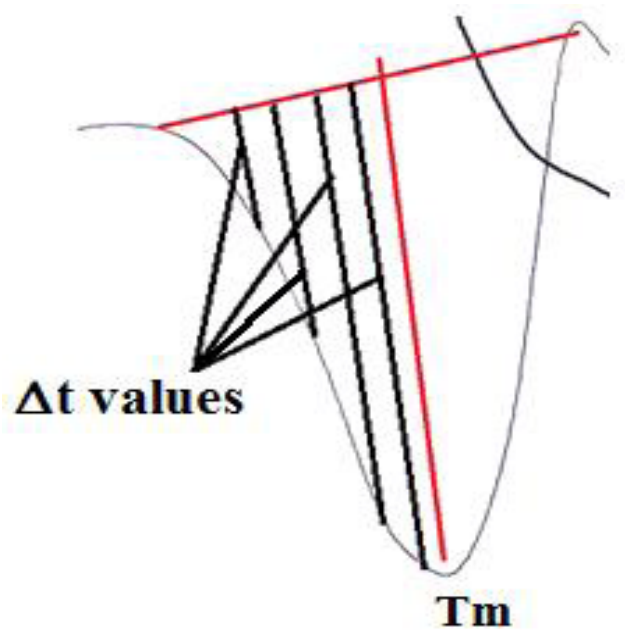

Figure 5: Measurements of $\Delta t$ values made on the DTA curve corresponding to different temperatures.

\section{The following conclusions can be drawn from the DTGA data:}

The activation energy $\Delta \mathrm{E}_{\mathrm{a}}{ }^{\theta}=59.814 \mathrm{kJmol}^{-1}$ for the endothermic peak and $330.066 \mathrm{kJmol}^{-1}$ for the exothermic trough. Thus, the final decomposition step where $\mathrm{NiO}$ is formed needs more activation energy than the preceding step. The appearance of fractional orders in the endothermic and exothermic peaks suggests that the reaction proceeds via a complicated mechanism. The change of entropy, $\Delta \mathrm{S}_{\theta}$, values were -0.22 and $-0.23 \mathrm{~kJ} \mathrm{~K}^{-1} \mathrm{~mol}^{-1}$ for both thermal transitions and are nearly of the same magnitude indicating that the transition states are more ordered than the reactants [38]. The calculated $\Delta \mathrm{H}_{\theta}$, were found to be -59.10 and $-121.89 \mathrm{kJmol}^{-1}$, respectively. The values of the collision number, $\mathrm{Z},\left(5.202\right.$ and $\left.7.313 \mathrm{~s}^{-1}\right)$ showed a direct relation to $\Delta \mathrm{E}_{\mathrm{a}}{ }^{\theta}$.

\section{Biological evaluation}

The $\left[\mathrm{NiL}_{2}(\mathrm{SCN})_{2}\right] .\left(\mathrm{NH}_{4}\right)_{2} 2 \mathrm{H}_{2} \mathrm{O}$ complex was found to be effective against E.coli (gram $\left.(-)\right)$ and $S$. aureus $($ gram $(+))$ bacteria, where its inhibition zone diameters were found to be 21 and $28 \mathrm{~mm} / \mathrm{mg}$ sample, respectively. Also, it was found to be effective against $C$. albicans fungus, where the inhibition zone was found to be $20 \mathrm{~mm} / \mathrm{mg}$ sample.

\section{X-ray Analysis - Discussion of the Structure}

[Note: The molecular geometry of both the $\mathrm{Cu} \mathrm{Ka}$ and synchrotron $\mathrm{X}$-ray structures is presented, values in square parentheses [ ] apply to the structure determined from synchrotron data.]

Ni Coordination: The $4 \mathrm{O}$ and $2 \mathrm{~N}$ atoms (Figure $3 \mathrm{~b}$ ) coordinated to Ni form a distorted octahedral arrangement. The 3 axial bond angles have an average value of $171.4(1.3)^{\circ}\left[171.4(1.3)^{\circ}\right]$ and the 12 equatorial bond angles an average value of $89.8(5.1)^{\circ}\left[\left(89.8(5.1)^{\circ}\right]\right.$ ideal values $180^{\circ}$ and $90^{\circ}$, respectively).

Pyridine Rings A1 and A2: The pyridine rings are both highly planar. Average bond lengths:

$\mathrm{C}-\mathrm{C}=1.383(14) \AA$ [1.384(15) $\AA$ ], $\mathrm{C}-\mathrm{N}=1.377(1) \AA ̊ 01.376(3) \AA]$. Average bond angles: $\mathrm{C}-\mathrm{C}-\mathrm{C}=120.1(6)^{\circ}\left[119.8(1.1)^{\circ}\right], \mathrm{C}-\mathrm{C}-\mathrm{N}=$ $119.7(9)^{\circ}\left[119.7(9)^{\circ}\right]$ and $\mathrm{C}-\mathrm{N}-\mathrm{C}=120.8(2)^{\circ}\left[120.6(2)^{\circ}\right]$.

Ni-O-N-C-O Rings: These two rings are also highly planar.

\section{Average bond lengths:}

$\mathrm{C}-\mathrm{O}=1.305(1) \AA ̊ ⒈ 303(5) \AA], \mathrm{N}-\mathrm{O}=1.338(7) \AA ̊, ~[1.3387(1) \AA]$,

$\mathrm{Ni}-\mathrm{O}=2.05(4) \AA[2.05(4) \AA]$.

Average bond angles:

$\mathrm{O}-\mathrm{C}-\mathrm{N}=119.0(3)^{\circ}\left[118.9(1)^{\circ}\right], \mathrm{C}-\mathrm{N}-\mathrm{O}=118.1(2)^{\circ},\left[118.1(6)^{\circ}\right]$,

$\mathrm{O}-\mathrm{Ni}-\mathrm{O}=80.0(5)^{\circ},\left[80.1(5)^{\circ}\right]$. 
Fused Ring Systems A1B1 and A2B2: Both fused ring moieties A1B1 and A2B2 (Figure 2), respectively are highly planar with esd's from their ring planes of $0.05 \AA[0.05 \AA]$ and $0.09 \AA[0.09 \AA]$, respectively and interplanar angle $75.64(3)^{\circ}\left[79.35(3)^{\circ}\right]$.

Thiocyanate: In the $\mathrm{S}=\mathrm{C}=\mathrm{N}$ - Ni ligands average bond lengths are:

$\mathrm{S}-\mathrm{C}=1.650(8) \AA[1.650(5) \AA], \mathrm{C}=\mathrm{N}=1.157(1) \AA[1.159(1) \AA]$,

$\mathrm{N}-\mathrm{Ni}=2.065(9) \AA[2.064(11) \AA]$.

With average bond angles of:

$\mathrm{S}-\mathrm{C}-\mathrm{N}=179.1(6)^{\circ},\left[179.3(7)^{\circ}\right], \mathrm{C}-\mathrm{N}-\mathrm{Ni}=173(7)^{\circ}\left[173(7)^{\circ}\right]$ the $\mathrm{S}=\mathrm{C}=\mathrm{N}-\mathrm{Ni}$ ligands are approximately linear .

\section{Least Squares Planes:}

(i) $\mathrm{A} 1 \mathrm{~B} 1 \mathrm{~N}(4) \mathrm{C}(12) \mathrm{S}(1)$ : This system is highly planar comprising 13 atoms having an rms deviation of the 13 fitted atoms of 0.11 $\AA[0.11 \AA]$.

(ii) $\mathrm{A} 2 \mathrm{~B} 2 \mathrm{~N}(3) \mathrm{C}(11) \mathrm{S}(2)$ : Also comprises 13 atoms and is highly planar with an rms deviation of the 13 fitted atoms of $0.22 \AA 0.22$ A].

Planes (i) and (ii) are approximately perpendicular with an interplanar angle of $87.12(1)^{\circ}\left[87.25(1)^{\circ}\right]$.

Hydrogen Bonding: The crystal structure is characterized by a number of strong hydrogen bonds listed in Table 4 . Figure 6 shows selected hydrogen bonds in this scheme drawn with MERCURY [29].

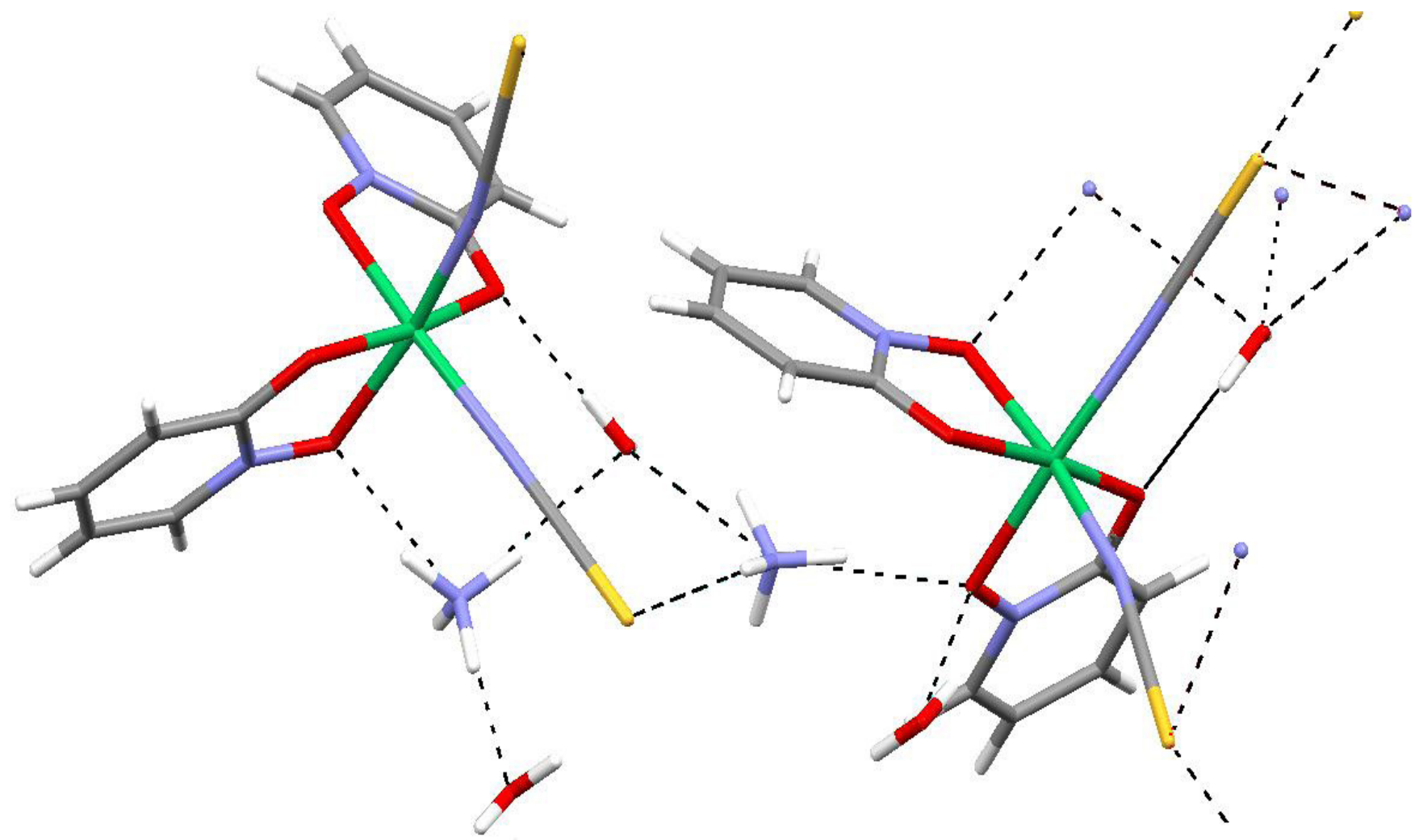

Figure 6:. Selected H-bonds in the crystal structure. Drawn with MERCURY [39]. See also Table 4.

\section{Conclusions from the X-ray Analyses}

The structural studies described here are distinguished by having been undertaken with two independent data sets measured (1) on a university diffractometer (Bruker Prospector with a microfocus source) and (2) on a CMOS flat plate detector with synchrotron radiation. The data in Tables $1 \mathrm{a}$ and $1 \mathrm{~b}$ indicate that both analyses are very high quality. It is of interest to summarize here the overall differences between these two results. The data in Table $5 \mathrm{a}$ gives an overview of the basic data qualities. This shows that the synchrotron data set is superior in the 4 categories: resolution, number of reflections, number of symmetry independent reflections measured and internal $\mathrm{R}$ factor R(int). As a result the final refinement R-factor R1 is also superior. Table 5b indicates the effect of this superiority on the values of a selection of the molecular geometry types of the refined structures. The synchrotron data values are significantly superior in all cases. This result may be important for future structural studies where selection of the best method, for example to distinguish or determine subtle bonding characteristics is a prime factor. 


\begin{tabular}{|l|l|l|l|l|}
\hline $\mathrm{D}-\mathrm{H} \ldots \mathrm{A}$ & $\mathrm{d}(\mathrm{D}-\mathrm{H})$ & $\mathrm{d}(\mathrm{H} \ldots \mathrm{A})$ & $\mathrm{d}(\mathrm{D} \ldots \mathrm{A})$ & $<(\mathrm{DHA})$ \\
\hline $\mathrm{N}(6)-\mathrm{H}(6 \mathrm{~F}) \ldots \mathrm{O}(5)$ & $0.91(4)$ & $2.06(4)$ & $2.965(3)$ & $172(3)$ \\
\hline $\mathrm{N}(6)-\mathrm{H}(6 \mathrm{E}) \ldots \mathrm{O}(2) \# \mathbf{1}$ & $0.94(4)$ & $1.92(4)$ & $2.823(3)$ & $162(3)$ \\
\hline $\mathrm{N}(5)-\mathrm{H}(\mathbf{5 F}) \ldots \mathrm{S}(2) \# 2$ & $0.91(3)$ & $2.38(3)$ & $3.281(2)$ & $171(3)$ \\
\hline $\mathrm{N}(5)-\mathrm{H}(5 \mathrm{E}) \ldots \mathrm{N}(1)$ & $0.94(4)$ & $2.68(4)$ & $3.511(3)$ & $149(3)$ \\
\hline $\mathrm{N}(5)-\mathrm{H}(5 \mathrm{E}) \ldots \mathrm{O}(4)$ & $0.94(4)$ & $1.87(4)$ & $2.783(3)$ & $164(3)$ \\
\hline $\mathrm{N}(5)-\mathrm{H}(5 \mathrm{D}) \ldots \mathrm{O}(5)$ & $0.97(3)$ & $1.98(3)$ & $2.818(3)$ & $143(3)$ \\
\hline $\mathrm{N}(5)-\mathrm{H}(5 \mathrm{C}) \ldots \mathrm{S}(1) \# 1$ & $0.94(4)$ & $2.42(4)$ & $3.312(2)$ & $158(3)$ \\
\hline $\mathrm{O}(5)-\mathrm{H}(5 \mathrm{~A}) \ldots \mathrm{N}(4) \# 2$ & $0.81(3)$ & $2.67(3)$ & $3.400(2)$ & $150(4)$ \\
\hline $\mathrm{O}(5)-\mathrm{H}(5 \mathrm{~A}) \ldots \mathrm{N}(3) \# 2$ & $0.81(3)$ & $2.41(3)$ & $3.038(2)$ & $135(4)$ \\
\hline
\end{tabular}

Symmetry transformations used to generate equivalent atoms: \#1 x+1/2,-y+1/2,z-1/2 \#2 x+1,y,z Table 4: Hydrogen bond geometry [A and ${ }^{\circ}$.

\begin{tabular}{|c|c|c|c|c|c|}
\hline Data Collection Method & Resolution Achieved & $\begin{array}{l}\text { Total Number of Reflections } \\
\text { Measured }\end{array}$ & $\begin{array}{l}\text { Number of Symmetry } \\
\text { Independent Reflections }\end{array}$ & $\mathrm{R}($ int $)$ & $\mathrm{R} 1$ for $\mathrm{I}>2 \sigma(\mathrm{I})$ \\
\hline $\begin{array}{l}\text { Conventional Laboratory Dif- } \\
\text { fractometer }\end{array}$ & $1.00 \AA$ & 11,142 & 3448 & 0.0455 & 0.0330 \\
\hline Diamond Synchrotron Pilatus & $0.73 \AA$ & 28,469 & 5011 & 0.0205 & 0.0220 \\
\hline
\end{tabular}

Table 5(a): Comparison of data and refinement parameters

\begin{tabular}{|l|l|l|l|l|l|}
\hline \multirow{2}{*}{ Data Collection Method } & \multicolumn{2}{|c|}{ Typical Bond Length esd's $\AA$} & \multicolumn{2}{c|}{ Typical Bond Angle esd's ${ }^{\circ}$} \\
\cline { 2 - 6 } & C - C & S - C & Ni - O & C - C - C \\
\hline Conventional Laboratory Diffractometer & 0.003 & 0.002 & 0.002 & 0.2 \\
\hline Diamond Synchrotron Pilatus & 0.001 & 0.001 & 0.0008 & 0.1 \\
\hline
\end{tabular}

Table 5(b): Comparison of molecular geometry esd's

\section{Conclusion}

The study described here successfully synthesized and characterized the $\mathrm{Ni}$ (II) Complex of 2-hydroxy-pyridine-N-oxide designated in full as: Ammonium $(\Delta / \Lambda)$-cis,cis,cis(bis(isothiocyanato)(bis(2-pyridinolate-1-oxide)- $\left.\kappa^{2} \mathrm{O}, \mathrm{O}^{\prime}\right)$ nickelate(II) dehydrate.

\section{Supplementary material}

Crystallographic data (excluding structure factors) for the structures reported in this paper have been deposited with the Cambridge Crystallographic Data Centre as supplementary publication nos. CCDC-974796 and 974797. Copies of available material can be obtained, free of charge, on application to the Director, CCDC, 12 Union Road, Cambridge CB2 1EZ, UK (fax: +44-(0) 1223-336033 or e-mail: teched@chemcrys.cam.ac.uk).

\section{Click here to download Supplementary File}

\section{References}

1) Lu KL, Kumaresan S, Wen YS, Hwu JR (1994) Novel Osmium N-Oxide Complexes from the Reaction of Triosmium Clusters with 1-Hydroxybenzotriazole. Organometallics 13: 3170-6.

2) Nagai K, Carter BJ, Xu J, Hecht SM (1991) DNA cleavage by oxygen radicals produced in the absence of metal ions or light. J Am Chem Soc 113: 5099-100.

3) Lobana TS, Bhatia PK (1989) Biochemical and biological applications of complexes of 2-mercaptopyridines with different metal ions. J Sci Ind Res 48: $394-401$.

4) Kovacs JA, Holm RH (1987) Structural chemistry of vanadium-iron-sulfur clusters containing the cubane-type $\left[\mathrm{VFe}_{3} \mathrm{~S}_{4}\right]^{2+}$ core. Inorg Chem 26: 711-8.

5) Rambo JR, Huffman JC, Christou G (1989) Novel coordination mode for oxygen: Preparation and properties of $\left(\mathrm{NBu}_{4}^{\mathrm{n}}\right)_{2}\left[\mathrm{~V}_{4} \mathrm{O}(\mathrm{edt})_{2} \mathrm{Cl}_{8}\right]$ containing a squareplanar oxide bridge. J Am Chem Soc 111: 8027: 29.

6) Peyroux E, Ghattas W, Hardré R, Giorgi M, Faure B, et al. (2009) Binding of 2-Hydroxypyridine-N-oxide on Dicopper(II) Centers: Insights into Tyrosinase Inhibition Mechanism by Transition-State Analogs. Inorg Chem 48:10874-6.

7) Orio M, Bochot C, Dubois C, Gellon G, Hardré R, et al. (2011) The versatile binding mode of transition-state analogue inhibitors of tyrosinase towards dicopper(II) model complexes: experimental and theoretical investigations. Chemistry 17: 13482-94.

8) Kontoghiorghes GJ (1987) 2-Hydroxypyridine-N-oxides: effective new chelators in iron mobilisation. Biochim Biophys Acta 924:13-8.

9) Mabicka A, Dumarcay S, Gelhaye E, Gerardin P (2004) Inhibition of fungal degradation of wood by 2-hydroxypyridine-N-oxide. Holzforschung 58: 566-8. 
10) Ribeiro da Silvaa MDMC, Matosa MAR, Mirandaa MS, Moraisb VMF, Jr Acree WE (2004) Experimental and theoretical study of the dissociation enthalpy of the N-O bond on 2-hydroxypyridine N-oxide: theoretical analysis of the energetics of the N-O bond for hydroxypyrydine N-oxide isomers. J Chem Thermodyn 36: 107-13.

11) Agarwal RK, Rastogi SC (1983) Infrared and thermal decomposition of pyridine N-oxide and substituted pyridine N-oxide complexes of thorium(IV) halides. Thermochim Acta 63: 363-8.

12) Bauer AW, Kirby WM, Sherris JC, Turck M (1966) Antibiotic susceptibility testing by a standardized single disk method. Tech Bull Regist Med Technol 36: 49-52.

13) Bruker (2001) SMART (Version 5.625), SADABS (Version 2.03a) and SHELXTL (Version 6.12). Bruker AXS Inc., Madison, Wisconsin, USA.

14) Bruker (2002) SAINT (Version 6.36a). Bruker AXS Inc., Madison, Wisconsin, USA.

15) Cosier J, Glazer MJ (1986) A nitrogen-gas-stream cryostat for general X-ray diffraction studies. J Appl Cryst 19: 105.

16) Sheldrick GM (1986) SHELX86, Program for crystal structure determination. University of Göttingen, Germany.

17) Sheldrick GM (1997) SHELXL97, Program for crystal structure refinement. University of Göttingen, Germany.

18) Farrugia LJ (1999) WinGX suite for small-molecule single-crystal crystallography. J Appl Cryst 32: 837-8.

19) Farrugia LJ (1997) ORTEP-3 for Windows - a version of ORTEP-III with a Graphical User Interface (GUI). J Appl Cryst 30: 565.

20) Merrit EA, Bacon DJ (1997) Raster3D: Photorealistic molecular graphics. Meth Enzymol 277: 505-24.

21) Collaborative Computational Project, Number 4 (1994) The CCP4 suite: programs for protein crystallography. Acta Crystallogr D Biol Crystallogr: 50: 760-3.

22) Evans P (2006) Scaling and assessment of data quality. Acta Crystallogr D Biol Crystallogr 62: 72-82.

23) Kabsch W (1988) Automatic indexing of rotation diffraction patterns. J Appl Cryst 21: 67-72.

24) Kabsch W (1988) Evaluation of single-crystal X-ray diffraction data from a position-sensitive detector. J Appl Cryst: 21: 916-24.

25) Kabsch W (1993) Automatic processing of rotation diffraction data from crystals of initially unknown symmetry and cell constants. J Appl Cryst 26: 795-800. 26) Kabsch W (2010) XDS. Acta Cryst D66: 125-132.

27) Winter G (2010) xia2: an expert system for macromolecular crystallography data reduction. J Appl Cryst 43: 186-90.

28) Winter G, Lobley CMC, Prince SM (2013) Decision making in xia2. Acta Cryst D69: 1260-1273.

29) (a) Luttke W (1954) Sur les frequencés de valence-N=O dans les composés nitroso. J Phys Rad 15: 633-40. (b) Nakamoto K, Randle RE (1965) Infrared spectra of inorganic coordination compounds. J Am Chem Soc 78: 1113-9.

30) Coss A, Cantor KP, Reif JS, Lynch CF, Ward MH (2004) Pancreatic cancer and drinking water and dietary sources of nitrate and nitrite. Am J Epidemiol 159: 693-701.

31) Satapathy J, Sahoo B (1970) Salicylaldazinate metal chelates and their IR spectra. J Inorg Nucl Chem 32: 2223-7.

32) Rao CNR, Venkataraghavana $\mathrm{R}$ (1962) The $\mathrm{C}=\mathrm{S}$ stretching frequency and the "-N-C=S bands" in the infrared. Spectrochimica acta 18: 541-7.

33) Gonzalez E, Rodrigue-Witchel A, Reber C (2007) Absorption Spectroscopy of octahedral nickel (II) complexes: A case study of interactions between multiple electronic excited states. Coord Chem Rev 251: 351-63.

34) Horowitz HH, Metzger G (1963) A new analysis of thermogravimetric traces. Anal Chem 35: 1464-68.

35) Kissinger HE (1957) Reaction kinetics in differential thermal analysis. Anal Chem 29: 1702-06.

36) Piloyan GO, Ryabchikov ID, Novikova OS (1966) Nature London 1229-36.

37) Dhar ML, Singh O (1991) Kinetics and thermal decomposition of Fe(III) and UO2(II) complexes with embelin (2,5-dihydroxy-3-undecyl-P-benzoquinone). J Therm Anal Calorim (259-265).

38) Mallikarjun KG, Naidu RS (1992) Thermal decomposition kinetics of $\mathrm{Cu}(\mathrm{II})$ chelates of substituted chalcones. Thermochim Acta 206: 273-8.

39) Edgington PR, McCabe P, Macrae CF, Pidcock E, Shields GP (2006) Mercury: visualization and analysis of crystal structures. J Appl Cryst 39: 453-7.

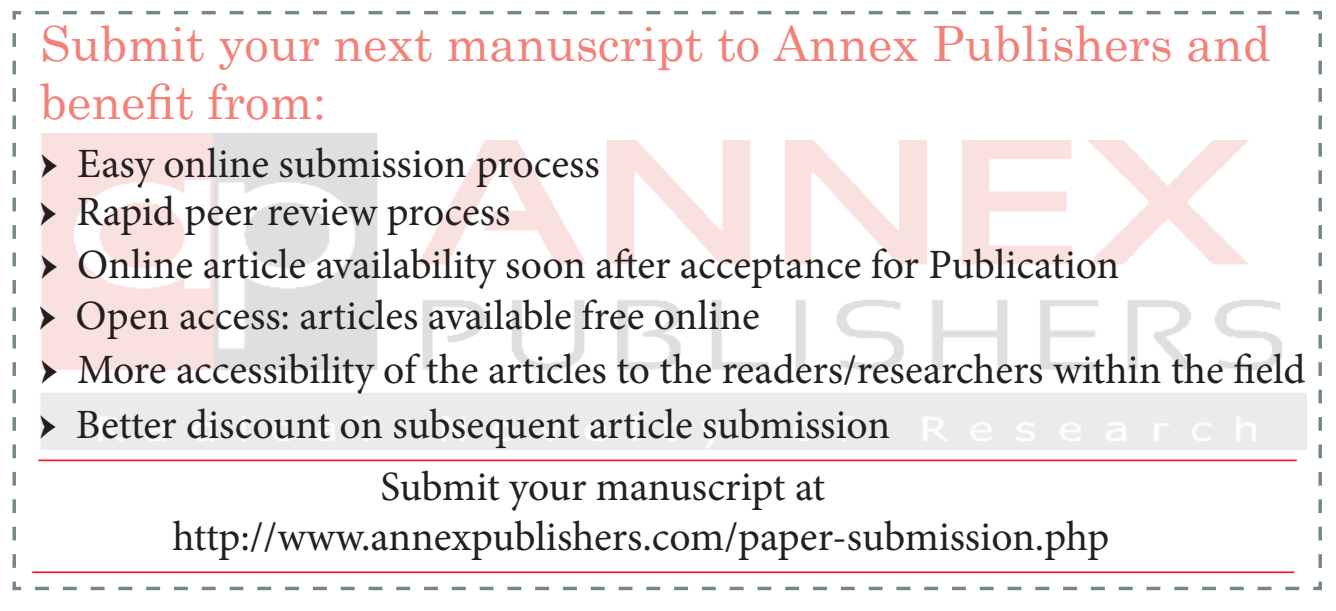

